\section{What is already known on this topic}

Patients undergoing elective coronary artery bypass surgery often need a blood transfusion

Recent meta-analyses have shown that the mechanical blood conservation techniques of intraoperative cell salvage and acute perioperative normovolaemic haemodilution may reduce the need for transfusion, but flawed methods in trials mean that clear evidence in cardiac surgery is lacking

\section{What this study adds}

Intraoperative cell salvage significantly reduces the number of patients needing an allogeneic blood transfusion

Combining acute perioperative normovolaemic haemodilution with intraoperative cell salvage does not confer any additional benefit

need to be given transfusions of allogeneic red blood cells and blood coagulation products.

Mr S Yates, manager of Haematology and Transfusion Laboratories, provided essential laboratory and transfusion support, without which this study could not have occurred. Dr D C Smith, consultant cardiac anaesthetist, reviewed the paper and made helpful comments.

Contributors: See bmj.com

Funding: This study was supported by a grant from the local blood transfusion service.

Competing interests: None declared.

1 National Blood Authority. Annual report 2000. www.blood.co.uk/pages/ f24Pubs.html

2 Killip T. Twenty years of coronary bypasss surgery. $N$ Engl J Med 1988;319:366-8

Renton MC, McClelland DB, Sinclair CJ. Use of blood products in cardiac surgery. Perfusion 1997;3:157-62

4 Dalrymple-Hay MJ, Pack L, Deakin CD, Shephard S, Ohri SK, Haw MP, et al. Autotransfusion of washed shed mediastinal fluid decreases the requirement for autologous blood transfusion following cardiac surgery: a prospective randomised trial. Eur J Cardiothorac Surg 1999;15:830-4.

5 Schreiber G, Busch M, Kleinman S, Korelitz J. The risk of transfusion-transmitted viral infections. N Engl J Med 1996;334:1685-90.

6 Duffy G, Neal KR. Differences in post-operative infection rates between patients receiving autologous and allogeneic blood transfusion: a meta-analysis of published randomised and nonrandomised studies Transfus Med 1996;6:325-8.

7 Spiess BD, Ley C, Body SC, Siegel LC, Stover EP, Maddi R, et al. Hematocrit value on intensive care unit entry influences the frequency of Q-wave myocardial infarction after coronary artery bypass grafting. The Q watutions of the Multicenter Study of Perioperative Thorac Cardiovasc Surg 1998:116:460-7.

8 Henry DA, Henderson KM, Fryer JL, Treloar CJ, McGrath KM, Deveridge SF. Use of interventions to minimise perioperative allogeneic blood transfusion in Australia. Med J Aust 2000;172:365-9.

9 Fergusson D, Blair A, Henry D, Hisashige A, Huet C, Koopman-van Gemert AW, et al. Technologies to minimise blood transfusion in cardiac and orthopaedic surgery: results of a practice variation survey in nine countries. International Study of Peri-operative Transfusion (ISPOT) Investigators. Int J Technol Assess Health Care 1999;15:717-28.

10 Huet C, Salmi LR, Fergusson D, Koopman-van Gemert AW, Rubens F, Laupacis A. A meta-analysis of the effectiveness of cell salvage to minimize perioperative allogenic blood transfusion in cardiac and orthopedic surgery. International Study of Peri-operative Transfusion (ISPOT) Investigators. Anesth Analg 1999;89:861-9.

11 Bryson GL, Laupacis A, Wells GA. Does acute normovolaemic haemodilution reduce perioperative allogeneic transfusion? A meta-analysis. The International Study of Peri-operative Transfusion. Anesth Analg 1998;86:9-15.

12 Hallowell P, Bland JHL, Buckley MJ, Lowenstein E. Transfusion of fresh autologous blood in open heart surgery: a method of reducing bank blood requirements. Thorac Cardiovasc Surg 1972;64:941-8.

13 Lawson NW, Ochsner JL, Mills NL, Leonard GL. The use of hemodilution and fresh autologous blood in open-heart surgery. Anesth Analg 1974;53:672-83.

14 Kaplan JA, Cannarella C, Jones EL, Kutner MH, Hatcher CR Jr, Dunbar RW. Autologous blood transfusion during cardiac surgery: a re-evaluation of three methods. Thorac Cardiovasc Surg 1977;74:4-10.

15 Lilleaasen P. Moderate and extreme haemodilution in open-heart surgery: blood requirements, bleeding and platelet counts. Scand J Thorac Cardiovasc Surg 1977;11:97-103.

16 Dale J, Lilleaasen P, Erikssen J. Hemostasis after open-heart surgery with extreme or moderate hemodilution. Eur Surg Res 1987;19:339-47.

17 Dietrich W, Barankay A, Dilthey G, Mitto HP, Richter JA. Reduction of blood utilisation during myocardial re-vascularisation. Thorac Cardiovasc Surg 1989;97:213-9.

18 Boldt J, Kling D, Weidler B, Zickmann B, Herold C, Dapper F, et al. Acute preoperative hemodilution in cardiac surgery: volume replacement with a hypertonic saline-hydroxyethyl starch solution. J Cardiothorac Vasc Anesth 1991;5:23-8.

19 Vedrinne C, Girard C, Jegaden O, Blanc P, Bouvier H, Ffrench P, et al. Reduction in blood loss and blood use after cardiopulmonary bypass with high-dose aprotonin versus autologous fresh whole blood transfusion. J Cardiothorac Vasc Anesth 1992;6:319-23.

20 Herregods L, Foubert L, Moerman A, Francois K, Rolly G. Comparative study of limited intentional normovolaemic haemodilution in patients with left main coronary artery stenosis. Anaesthesia 995;50:950-3.

21 Triulzi DJ, Gilmor GD, Ness PM, Baumgartner WA, Schultheis LW. Efficacy of autologous fresh whole blood or platelet-rich plasma in adult cardiac surgery. Transfusion 1995;35:627-34.

22 Kochamba GS, Pfeffer TA, Sintek CF, Khonsari S. Intraoperative autotransfusion reduces blood loss after cardiopulmonary bypass. Ann Thorac Surg 1996;61:900-3.

23 Rao TKL, Montoya A. Cardiovascular, electrocardiographic and respiratory changes following acute anemia with volume replacement in patients with coronary artery disease. Anesthesiol Rev 1985;12:49-54.

(Accepted 5 December 2001)
Science commentary

Abi Berger science editor, BMJ

\title{
Science commentary: Why is it important to reduce the need for blood transfusion, and how can it be done?
}

Reducing the need for blood transfusions is desirable for several reasons. Since 2000 in the United Kingdom it has been mandatory to remove all white cells from donated blood to reduce the small but theoretical risk of prion disease (variant Creutzfeldt-Jakob disease). This has trebled the cost of providing donated blood. Transmission of hepatitis $\mathrm{B}$, hepatitis $\mathrm{C}$, and HIV by transfusion occurs in 1 in 300000 cases, despite screening programmes. ${ }^{1}$ However, non-fatal but serious transfusion errors occur in 1 in 16000 transfusions. ${ }^{1}$

Critically ill patients are now known to do just as well with a lower haemoglobin concentration than previously thought, thus reducing the need for top-up trans- fusions. ${ }^{2}$ There is also some evidence that homologous blood transfusions increase the rates of recurrence of some cancers (tumours of the bowel and oesophagus, in particular) and can increase the incidence of wound infections. ${ }^{3}$ It is unclear why these phenomena occur.

A number of mechanical methods have been developed to help reduce the need for postoperative blood transfusions. In the United States erythropoetin injections or autologous blood donations (or both), given preoperatively, are commonly used. Both require the exact date of surgery to be known-but neither process is free from human error in labelling, storing, and administration. 
Perioperative dilution and intraoperative blood salvage techniques (such as those described in this paper) are gaining credence, particularly for patients undergoing cardiac and orthopaedic surgery. But neither of these processes is suitable for patients with infection or malignant disease.

After surgery, devices are available to collect blood from wound drains, which can then be retransfused back into the patient. Such techniques reduce the formation of haematomas, but few studies of their efficacy are available, and the techniques are not in general use. ${ }^{4}$
1 Williamson L, Cohen H, Love E, Jones H, Todd A, Soldan K, et al. The Serious Hazards of Transfusion (SHOT) Initiative. Vox Sang 2000;78(suppl 2):291-5.

2 Hebert PC, Wells G, Blajchman MA, Marshall J, Martin C, Pagliarello G, et al. A multicenter, randomized, controlled clinical trial of transfusion requirements in critical care. Transfusion Requirements in Critical Care Investigators, Canadian Critical Care Trials Group. $N$ Engl J Med 1999:340:409-17.

3 Tang R, Chen HH, Wang YL, Changchien CR, Chen JS, Hsu KC, et al. Risk factors for surgical site infection after elective resection of the colon and rectum: a single-center prospective study of 2,809 consecutive patients. Ann Surg 2001;234:181-9.

4 Parker MJ, Roberts C. Closed suction surgical wound drainage after orthopaedic surgery Cochrane Database Syst Rev 2001;4: CD001825.

\title{
Cost effectiveness analysis of different approaches of screening for familial hypercholesterolaemia
}

\author{
Dalya Marks, David Wonderling, Margaret Thorogood, Helen Lambert, Steve E Humphries, \\ H Andrew W Neil
}

\section{ELPS}

The full version of this article appears on bmi.com

\author{
Abstract \\ Objectives To assess the cost effectiveness of \\ strategies to screen for and treat familial \\ hypercholesterolaemia. \\ Design Cost effectiveness analysis. A care pathway for \\ each patient was delineated and the associated \\ probabilities, benefits, and costs were calculated. \\ Participants Simulated population aged 16-54 years \\ in England and Wales. \\ Interventions Identification and treatment of patients \\ with familial hypercholesterolaemia by universal \\ screening, opportunistic screening in primary care, \\ screening of people admitted to hospital with \\ premature myocardial infarction, or tracing family \\ members of affected patients. \\ Main outcome measure Cost effectiveness calculated \\ as cost per life year gained (extension of life \\ expectancy resulting from intervention) including \\ estimated costs of screening and treatment. \\ Results Tracing of family members was the most cost \\ effective strategy ( $£ 3097(€ 5066, \$ 4479)$ per life year \\ gained) as 2.6 individuals need to be screened to \\ identify one case at a cost of $£ 133$ per case detected. If \\ the genetic mutation was known within the family \\ then the cost per life year gained (£4914) was only \\ slightly increased by genetic confirmation of the \\ diagnosis. Universal population screening was least \\ cost effective (£13 029 per life year gained) as 1365 \\ individuals need to be screened at a cost of $£ 9754$ per \\ case detected. For each strategy it was more cost \\ effective to screen younger people and women. \\ Targeted strategies were more expensive per person \\ screened, but the cost per case detected was lower. \\ Population screening of 16 year olds only was as cost \\ effective as family tracing ( $£ 2777$ with a clinical \\ confirmation). \\ Conclusions Screening family members of people \\ with familial hypercholesterolaemia is the most cost \\ effective option for detecting cases across the whole \\ population.
}

\section{Introduction}

Familial hypercholesterolaemia is an autosomal dominant condition caused mainly by mutations of the low density lipoprotein receptor gene. ${ }^{1}$ Men with this condition have over a $50 \%$ risk of coronary heart disease by the age of 50 years. For women the risk is at least $30 \%$ at 60 years. ${ }^{2}{ }^{3}$ About 110000 people in the United Kingdom are thought to be affected, and at least $75 \%$ of them are undiagnosed. ${ }^{4}$ Treatment with hydroxymethyl glutaryl coenzyme A (HMG-CoA) reductase inhibitors (statins) is effective $\mathrm{e}^{56}$ and delays or prevents the onset of coronary heart disease. ${ }^{7-10}$ Effective primary prevention, however, requires early diagnosis.

A diagnosis of familial hypercholesterolaemia is made on the basis of the plasma total and low density lipoprotein cholesterol concentrations combined with either a clinical examination and family history ${ }^{11}$ or a genetic test.

We carried out a modelling exercise to determine the costs and benefits of different screening strategies in the United Kingdom.

\section{Methods}

We identified potential screening strategies in a systematic literature review ${ }^{12}$ : universal population screening; opportunistic screening of patients consulting for unrelated reasons in primary care; opportunistic screening of patients admitted to hospital with premature myocardial infarction; and systematic screening of first degree relatives of people with diagnosed familial hypercholesterolaemia. We added to these the option of screening all young people aged 16 years.

We developed a hypothetical care pathway. In the universal and opportunistic strategies, people with a non-fasting total cholesterol concentration above the population 95th centile are invited for a fasting blood test. Those with a confirmed fasting total cholesterol concentration above $7.5 \mathrm{mmol} / \mathrm{l}$ and low density lipoprotein cholesterol above $4.9 \mathrm{mmol} / 1$ are referred for 